\title{
MATRIX OF COGNITIVE DOMAINS FOR KOMI LOCAL CASES
}

\author{
Nikolay Kuznetsov \\ University of Tartu
}

\begin{abstract}
The semantics of local cases in the framework of the theory of cognitive linguistics has got an internal organization in the form of a matrix of cognitive domains, wherein each of them demonstrates the schematization of the choice of some concrete situation. The zones of its crossing indicate on the parts of the transition from one domain to another. Partial usages of cases belonging to transitional parts are peripheral in respect to prototypical ones. Space has got the central place in the matrix of cognitive domains being the basic cognitive field for all local cases. Anyway, all the other cognitive domains are somehow connected with space having got more or less similarity with it. I'm trying to perform a matrix of cognitive domains for spatial cases of the Komi language analogically with the analysis of cognitive domains of external local cases in the Estonian language (see Vainik 1995).
\end{abstract}

Keywords: cognitive linguistics, cognitive domain, domain matrix, case semantics, local cases, Komi

\section{Introduction}

Spatial (or local) cases are emphasized in a separate group together with subjective, relevance and transitive cases on the basis of the uniformity of main meanings in the system of declension of Komi language (for example, Nekrasova 1998: 336, SKJa 137-139, ÖKK 63, 64).

The group of local cases of modern literary Komi language includes 13 members (see Fig. 1). Seven of them could be conditionally named as traditional: INessive, ELative, ILLative, PROLative, APPRoximative, EGRessive and TERMinative. The residual six, which are called approximately local, include a set of cases of latter origin: APPRoximative-INessive, APPRoximative-EL- 
ative, APPRoximative II, APPRoximative-PROLative, APPRoximativeEGRessive and APPROXimative-TERMinative. The latter ones include co-affix -lan'-, which is added to all traditional markers except APPR. One of the characteristic features of Komi language is the presence of a wide spectrum of case forms with spatial semantics.

\begin{tabular}{|c|c|c|}
\hline Subjective & Nominative & $\varnothing$ \\
\hline & Genitive & $-l \ddot{o} n^{l}$ \\
\hline Possessive & Ablative & $-l y s^{\prime}$ \\
\hline & Dativ & $-l y$ \\
\hline & Accusative & $-\ddot{o s}, \varnothing$ \\
\hline & Instrumental & $-\ddot{o n}$ \\
\hline Objective & Comitative & $-k \ddot{d} d$ \\
\hline & Abessive & $-t \ddot{g} g$ \\
\hline & Consecutive & $-l a$ \\
\hline & Preclusive & $-s j a$ \\
\hline & Inessive & $-y n$ \\
\hline & Elative & $-y s^{\prime}$ \\
\hline & Illative & $-\ddot{o}$ \\
\hline & Prolative $1 \& 2$ & $-\ddot{o} d \&-t i$ \\
\hline & Approximative & -lan’ \\
\hline & Egressive & -sjan' \\
\hline Local & Terminative & $-\ddot{o} d z$ \\
\hline & Approximative-inessive & -lan'yn \\
\hline & Approximative-elative & -lan'ys' \\
\hline & Approximative II & -lan’ $\ddot{0}$ \\
\hline & Approximative-egressive & -lan'sjan' \\
\hline & $\begin{array}{l}\text { Approximative-prolative } \\
\text { Approximative-terminative }\end{array}$ & $\begin{array}{l}\text {-lan'öd, -lan'ti } \\
\text {-lan'ödz }\end{array}$ \\
\hline
\end{tabular}

Figure 1. Case system of Komi literary language, main declension (by Lytkin 1955, Fedjunëva 2000).

1 Cyrillic examples in Komi language are transliterated according to transliteration rules of JEFUL and only specific Komi $\ddot{o}$ is kept in its original form because of lack of this letter in Cyrillic alphabet. 
Spectrum of multifarious meanings, which is expressed by local cases, is varied by its wideness from case to case. As the primary local cases of Komi language are ambiguous as a rule, so the approximately local cases unlike them are limited to the expression of spatiality and in the case of some of them to time connections. The most ambiguous local cases, except especially spatial meanings, could express different pertinent ${ }^{2}$ and other connections.

The semantics of local cases in the frames of the theory of cognitive linguistics has got an internal organisation as a matrix of cognitive domains. Cognitive domains are some kind schematic generalisations of concrete case usages. Some of the case usages, which belong to one or another domain, can be more prototypical, the others can be more peripheral. Peripheral usage of cases belongs to the sections of transition from one domain to another and at the same time it's situated in the zone of cognitive domains crossing. Space has taken the central place in the matrix of cognitive domains, so it's the main cognitive domain.

\section{Physical space}

This domain presents all local cases of modern Komi language. All of them include the indication of moving or localisation in physical space in modern semantics:

(2) Menam mon'öj olö Syktyvkar-yn (IN) ... (Čuškanzi 31.08.2007)

'My daughter-in-law lives in Syktyvkar'

(3) Mijan sikt-ö (ILL) kar-ys' voöm velödys' jasyd... (Čuškanzi 23.04.2007)

'The teachers who have arrived to our village from a city...'

(3) Mijan sikt-ö kar-ys' (EL) voöm velödys'jasyd... (Čuškanzi 23.04.2007)

'The teachers who have arrived to our village from a city...'

2 For example, dialect use of EL as the marker of direct object (Guljaev 1961: 11): (1) nü̈ gortas ta-ys'

'bears her/him home'. 
(4) Pydöstöm jenèž-öd (PROL 1) kyvtisny šočinik jedžyd kymör" jas (ÖKK 89)

'On the bottomless $\underline{\text { sky }}$ rare white clouds floated'

(5) Pemyd vör-ti (PROL 2) munö oš (ÖKK 91)

'On a dark wood goas a bear'

(6) Vörz'ödčim vör kerka-lan' (APPR) vodz (Parma gor 03.11.2007)

'We began to move in the direction of lodge early'

(7) Dar' ja bereg-sjan' (EGR) vidzödö (Čuškanzi 23.04.2007)

'Darja is looking from the direction of the coast'

(8) Kaji bör aslam sudta-ödz (TERM) ... (Čuškanzi 31.08.2007)

'I went up to my floor...'

(9) ...Uhtayn-tulys, Letka-lan'yn (APPR-IN) - gožöm... (ÖKK 91)

'...there's spring in Uhta and summer on the side in the direction of Letka...'

(10) ...Syktyv jusajsa vidz'jas-lan'ys' (APPR-EL) ... (ÖKK 92)

'...from the direction of the meadows over the Sysola (Komi Colкmblв)'

(11) ...lèbisny Kyruv vičko-lan'ö (APPR II) (ÖKK 92)

'...flied away in the direction of church'

(12) Sikt-lan'sjan' (APPR-EGR) pöl'tis kujöd duk (ÖKK 92)

'I smelled of dung from the direction of the village'

(13) Tujys munis vör-lan'ti (APPR-PROL) ... (ÖKK 92)

'The track led on the side near the wood'

(14) Ves'ködčis tödsa vör-lan'ödz (APPR-TERM) (ÖKK 93)

' $[(\mathrm{S}) \mathrm{he}]$ went in the direction of familiar wood'

Space is seen in another way in language as in real physical world; it's a little more simplified. Spatial expressions are based on canonical conceptions of geometrical and physical world, that's why it's connected with idealized representation of space. A conception of that kind is sometimes called mental model of space (Frawley 1992: 250, 253-254, 337).

That's why the mentally projected three-dimensional space is considered as a space here. It may appear as three-dimensional, two-dimensional or one-dimensional according to the character of the landmark and functions of the cases: 
Three-dimensional: kerka-yn (IN) 'in the house'

Two-dimensional: $\quad d z \check{z} o d z ̌-y s '$ (EL) 'from the floor'

One-dimensional: tuj-ti (PROL) 'on the road'

Thereby conformity is specialized by the amount of dominant measurements in the matrix of the word (Vainik 1995: 50). A naive linguistic conception of space enables floor, which has got two dominant measures in real world, to be idealized as a plane in language, but road, which has got more projection in one direction, is idealized as one-dimensional space, that means practically as a line, in language etc.

It's difficult to define conformity monosemantically in some cases, that's why conformity of space is idealized as far as zero:

(15) Ačyssö völöma kys’kö Piter-ys' (EL) (ÖKK 86)

'Himself was somewhere from St. Petersburg'

Variously from Baltic-Finnish languages, wherein a special set of cases is used to determine localization on some surface, which is parallel with the internal localization, as a rule postpositional constructions and in special cases internal local cases are used for expressing localization on some surface in Komi language. Special cases include means of orientation without internal cavity, for example floor, board, shelf, wall etc.

Certain objects have got conventional attitude to the landmark (Vainik 1995: 76). That's why our understanding of their localization proceeds from our "encyclopaedic" knowledge of the surrounding world rather than from the grammatical forming.

(16) Fedja neť̌yštis kerj-ys' (EL) kyrs' tor... (ÖKK 85)

'Fedja tore a piece of bark from the trunk'

Human body and its parts could be considered to be a special subdivision of space. Indefinable conformity is revealed by them and internal local cases may include indications as on surfaces, so for internal space as is demonstrated by the following examples in ILL:

(17) ...jur-as (ILL.POSS3SG) puktis vyl' šapkasö da petis (Popov 2008: 300)

'...he put on his/her head a new cap and went out' 
(18) ...myjlakö jur-as (ILL.POSs3sG) vois tatšöm mövp... (Popov 2008: 317)

'...an idea of that kind came to his head for some reason...' The landmark of example (17) is appreciated as a surface, but in (18) exactly the same formulation in another environment is definitely carrying the meaning of internal localization, even in mental imagination.

The first situation is a typical example of the usage of the parts of human body in the form of internal local cases as the function of landmark for expressing wearing, dressing and undressing, putting on and taking off shoes, similarly watches, jewellery, toilet requisites etc. The following examples should be examined:

(19) Sèssja i kok-s'yd (EL.Poss2sG) us'as (Popov 2008: 31)

'[The slippers] will fall from your feet after that'

(20) Sèssja möd kok-s'ys (EL.POss3sG) kömsö vežis... (Popov 2008: 32)

'(S)he changed the shoe from the other foot after that'

(21) Katja [...] sjujis kuš kok-as (ILL.POss3sG) vajöm sapögsö. (Popov 2008: 32)

'Katja [...] put the brought shoes on bare feet'

Objectively, clothes, shoes etc. could be worn (dressed and undressed) no other way than on the surface of body covering a corresponding part of it. That's why there isn't fundamentally any direct necessity for stressing the surface. In fact, there are cases of using the constructions together with postpositions in addition to the cases. These postpositions include references to surface localization (see (17)):

(22) Nö ta na i s'ödinik röma čyš jan jur vylas (PP.POSs3SG) puktöma (Popov 2008: 34)

'She put a blackish scarf on her head'

Similar localization has been expressed by different grammatical means in the following pair of examples:

(23) ...pel'pom-as (ILL.POSS3sG) öšödöma gazet-žurnal tyra nopsö... (Komi mu 07.07.2007)

'...a bag fulfilled with newspapers and magazines has been put on his shoulder...' 
(24) ...vesig sumkaöj pel'pom vylys' mynöma... (Komi mu 10.11.2007)

'...even the bag was torn from my shoulder...'

However, the parallel expression of the same semantic role through declensional and postpositional constructions has got limitations: it's possible in case of some parts of body and impossible in the case of others. Namely, if the marking with the constructions of postpositions is allowed clothes, dressing and undressing etc. in the case of face, head (see (22)) and shoulders (see (23)), it won't be allowed as about fingers, hands, legs, neck, ears and some other parts of body. The latter ones could be used only with declensional forms in this context:

(25) Korsjurö čun-j-as (IN.POss3sG) dzirdyštlis almaz... (Timin 2000: 242)

'Sometimes a diamond was shining on her finger...'

(26) pörččis ki-s’ys (EL.POSs3SG) kepys'sö (Guljaev 1961: 49)

'(S)he took of the gloves from his/her hand'

(21) Katja [...] sjujis kuš kok-as (ILL.POSs3sG) vajöm sapögsö. (Popov 2008: 32)

'Katja [...] put the brought shoes on her bare feet'

(27) ...zarni medal'tö öšlöny SŠA-sa [...] sportsmen”jasly s'yli-as (ILL.POSs3sG) (Komi mu 07.08.2007)

'...the golden medals are put round the necks of US sportsmen $[\ldots]$ '

(28) ...pel-j-as (IN.POSs3sG) jug”'jalö zarni... (Vyl' tujöd 28.04.2007)

'...gold is shining in her ear...'

The situations of figuring other objects than clothes as the trajector, including abstract meanings, aren't rare, too. But the corresponding parts of body are taken as surface due to the context and primarily semantics of verbs in them regardless of the forming of landmarks with markers of internal local cases:

(29) ...ködzyd synödys čyškyštis čužöm-s'ynys (EL.POSs3PL) unzil'sö... (Guljaev 1961: 48)

'...frosty air wiped sleepiness away from their faces...'

(30) Drug kodkö nebydika šlapkis börsjan' pel'pom-ö (ILL[POSs1sG]) (Komi mu 02.10.2007)

'Suddenly somebody slightly knocked [me] on my shoulder from behind' 
(31) Körtalöm mužiklys' razisny kok-s'ys (EL.POss3sG) gezsö (Popov 2008: 368)

'They tied a rope around the feet of the caught man'

Thereby, it's as follows in case of the metaphorical transmission of the parts of body to lifeless objects:

(32) ...fotosnimok myšk-as (IN.POSS3SG)... (Komi mu 03.07.2007)

'...on the back of the photo...'

The expression of spatial connections as historically primary ones establishes all the others (Anderson 1971: 12-13). The meanings are transmitted from the physical world to abstract meanings and no other way round. Correspondingly, all the other cognitive domains are somehow connected with space and exhibit more or less equability with it. Spaces, which exhibit more equability with physical space, have got zones of direct crossing with it.

\section{Abstract space}

Words, which indicate to different abstract meanings act as landmarks in declensional constructions connected with the domain. The same structural models as for physical spaces are used:

(33) ...politika-yn da èkonomika-yн (IN) jözköd jitöd kutan agenstvoön ves'ködlys'... (Komi mu 03.11.2007)

'...the manager of the agency of political and economic communications (word to word in politics and economics)...'

(34) ... "Beloje solnce pustyni" kino-ys' (EL) ... (Komi mu 08.05.2007)

'...from the film "White sun of desert"...'

(35) ...ydžyd nauka-ö (ILL) tujys... (Komi mu 07.07.2007)

'...way to big science...'

(36) Lyddjan najös da pyr žö kazjalan, kutšöma kyskö gižöd”jassö muzyka-lan' (APPR) (Komi mu 19.06.2007)

'You're reading their [poems] and you'll understand how similar to music their creations are (word to word it's pulling in the direction of music)' 
(37) ...kolö bör bergödčyny literatura-lan' (APPR) (Komi mu 04.12.2007)

'...we have turn to literature (word to word in the direction of literature) once again'

(38) ...Rossija pö zumyda vos'lalö jugyd-lan' (APPR) ... (Komi mu 09.06.2007)

'...Russia is going with confidence to light (word to word in the direction of light)...'

\section{Event space}

Event space is characterized by the usage of local cases in landmarks, which somehow mark an event. Verbal nouns, which mark process, special "event" words and different words, which mark place, time etc., are usually of that kind (Vainik 1995: 113, Kondrat'eva 2010: 156). For example:

(39) ...ysta komandirovka-ö (ILL) Iz’va vylö (ÖKK 83)

'...I'll send [her/him] on a business trip to Izhma'

Sometimes just a part of an event can metonymically indicate to it, for example result/object of activity:

(40) idj-ys' (EL) loktö (Guljaev 1961: 28)

'(s)he is coming back from the harvest of barley'

... or the content of activity:

(41) Dum”jas-ad (IN.POss2sG) stavys artmö... (Popov 2008: 313) 'Everything always works in your mind'

Prototypical events are characterized by activity in time and space. Different aspects can be stressed in concrete cases of cases usage. That's why event space may have zones of crossing with other domains (Vainik 1995: 113, Kondrat'eva 2010: 156).

If the local cases are used with landmarks, which clearly belong to the domain of physical space, but which have got reference to an event, the participation in the event from one side and entering, being etc. side in the place, wherein the activity takes place from the other, is assumed. Cases of that kind belong to transitional zone between physical and event cases: 
(42) Vitöd klassjan' zavoditi vetlödlyny èkologija kružok-ö (ILL) (Komi mu 14.04.2007)

'[I] began to attend ecological club from $5^{\text {th }}$ class'

(43) Petyr da Ped'ö askinas vodz petisny tuj-ö (ILL) ... (ÖKK 83)

'Pjotr and Fjodor began their trip (word to word went to $\underline{\text { road }}$ ) tomorrow early in the morning...'

We can talk about the crossing of event and time spaces in cases, wherein the events are expressed by the landmark, which marks process. The extension of the events is emphasized in such cases:

(44) sërnijas-ys' (EL) töda

'I know [it] from the talks'

(45) ....spor-ö (ILL) voasny... (ÖKK 83)

'...they got into dispute...'

(46) Najö bertčöm- ö (ILL) voisny. (ÖKK 83)

'They began fighting (word to word they entered fight)'

\section{Social space}

The social space clearly resembles the physical one as relocations to different directions and incidentally real relocations are possible. But the organization according to the conformity is missing in social space and it's characterized by liveliness of landmark. As a rule, these are man, people, collective etc.:

(47) Tè pö udžač sem’ja-ys' (EL) ... (ÖKK 86)

'It's said that you're from a hardworking family...'

EGR has helped to create many examples, which exposit social space and that's why the landmark demonstrates, where the activity originates from. It's often expressed in situations of appropriation, getting something form somebody in constructions with corresponding verbs or verbal formations or without them (the verbal activity is assumed):

(48) Tödčömön sodis olys'jas-sjan' jöv da jaj bos'töm (Komi mu 22.11.2007)

'The purveyance of milk and meat from inhabitants has significantly increased' 
(49) Prezident-sjan’ 60 sjurs šajt (Komi mu 04.12.2007) '60 thousand roubles from President'

(50) ...kyvjys' kyvjö lyddis Komi Respublikasa Juralys-sjan' telegramma... (Komi mu 01.12.2007)

'...(s)he read the telegram from the Head of Komi Republic word to word...'

The constructions with verb tödmavny 'get to know, find out', kyvny 'hear' and other verbs of similar character are common:

(51) Unays' me s'yvlyvli, jöz-sjan' (EGR) “att'ö” kyvlyvli (ÖKK 88)

'As much as I've sung, I've heard "thank you" from people'

(52) Nekor èg kyvly bat'-sjan' (EGR[POSs.1SG]) ërččan kyv (Komi mu 02.08.2007)

'I have never heard abusive words from my father'

(53) ...sömyn bur kyv"jas kyvlim sy-sjan' (EGR) ... (Komi mu 04.12.2007)

'...we heard only good words from him...'

(54) ...una vyl'tor sèki tödmali brigadir Fëdor Vasil'jevič Xozjainov-sjan' (EGR) (Komi mu 14.06.2007)

'I learned many new things from foreman Fëdor Vasil'jevič Xozjainov'

The object of displacement can't be visibly observed, but the displacement itself - movement of sound waves - however exists (the case of kyvny in (51), (52) and (53)) or it can be mentally imagined (transition of information in the case of tödmavny in (54)).

The displacement of some abilities in the following example can be called just mental and it could exist only in the minds of the speakers', but it should be named conceptual according to the analogy of real displacement of things in material world:

(55) Sy-sjan' (EGR), čajta, i menym vudžis morttujys (Komi mu 11.10.2007)

'I think, the ability has come to me from her'

The initial moment of schema displacement has been indicated in the following example by the form of case:

(56) Möd nylös na čužtis Ivan-sjan' (EGR) Ögašyd (Komi mu 07.08.2007)

'Ögaš gave birth the second daughter from Ivan' 
The quasi-alive objects as institutes, organizations etc., which function as alive ones, could function as landmarks in some situations (Vainik 1995: 85):

(57) ...ydžyd otsög pyr voö Komi pravitel'stvo-sjan’ (EGR) da Sankt-Peterburgsa predstavitel'stvosa udžalys' jassjan'... (Komi mu 01.12.2007)

'...government of Komi and the workers of embassy in St. Petersburg always help (word to word the help comes from government...)'

(58) Kydzi juörtisny [...] respublikasa minzdrav-sjan' (EGR) ... (Komi mu 04.12.2007)

'As it was announced [...] from Ministry of Health...'

(59) ...Komi Respublikasa Gossövet-ö (ILL) loi börjöma 29 deputatös (Komi mu 22.03.2007)

'...29 delegates were elected to Parliament of Komi Republic'

Proper names and relative terms in plural in the form of internal local cases are given in the meaning of 'at somebody's home' (ÖKK 81, 83):

(60) Bisinys koras'ny mödödas bat'-mamsö Ma ajas-ö (ILL) (ÖKK 83)

'Bisin sends his father and mother home to Masha (word to word into Mashas) to propose [Masha] as a wife'

(61) Ydžyd mamöjas-yn (IN) jaja šydön verdisny (ÖKK 81)

'[I] was fed with meat soup at the grandmother's (word to word in the grandmothers)'

(62) Voj šör böryn gös't”jas razödčisny [...] Vavilov”jas-ys' (EL) (Popov 2008: 296)

'The guests disbanded from the Vavilovs after midnight'

There are examples of the usage of such names in literature in singular in spite of the rules:

(63) Sava Sandra-yn (IN), tydalö, vojpukisny žö, èz na uz'ny (Popov 2008: 315)

'Probably no one was sleeping at Sava Sandra's house (word to word in Sava Sandra)'

Anyway, social space crosses physical space in case usages of that kind: the landmark without case suffix indicates to a 
collective of people (plural form comes from here), as a rule to a family, and in the form of local cases it expresses the habitation of the collective, it means a special area of physical space.

\section{Time}

Time is considered to be one of basic cognitive domains (for example, Langacker 2008: 53). It's an abstract domain, which is represented in the form of one-dimensional and oneway space, and that's why it's systematically described in spatial terms: everything, which doesn't take place in real life, is placed on a time axle as points or segments (Vainik 1995: 117-118, 122).

The units of time counting and different words, which "by default" contain some indication on a moment or a period of time in the form of different local cases, indicate to time the most frequently:

(64) tulys-yn (IN)

'in spring'

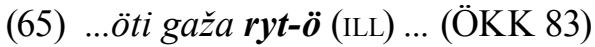

'...in a beautiful evening...'

(66) Ryt-lan'-ys (APPR) ködzdödis (ÖKK 87)

'It became colder in the evening'

The words, which mean some event, could be the landmarks of time quite often in addition to it. The usages of that kind are situated in the transition zone of time and event spaces:

(67) A mi pažyn-ödz (TERM) na stavsö èštödim (ÖKK 90)

'But we did everything before lunch'

(68) ...va vylö petöm-sjan' (EGR) kolis nin časys' undžyk (ÖKK 88)

'...more than an hour has expired since [the moment of] going to the water'

(69) Zavoditöma kysjan kružok-sjan' (EGR) ... (Komi mu 10.11.2007)

'(S)he began from a knitting circle...' 


\section{State, condition}

Some of the local cases are used in the constructions for expressing a condition. Conformity is missing in the domain but the same structural models as in physical space (entering, staying, or leaving in a condition) are used for expressing relations between the trajector and landmark:

(70) ...Sandra olis ydžyd šog-yn (IN) ... (ÖKK 82)

'...Sandra was broken-hearted (word to word in great sorrow)...'

(71) ...sem'jays nalön èz petavly göl'lun-ys' (EL) ... (ÖKK 84) '...their family didn't cope with necessities (word to word exit from poverty)'

Words-landmarks of abstract character in conditional expressions with verbs $y s$ 'ny 'fall' and $u s$ ' $k o ̈ d n y$ 'let to fall, drop' are often present in the form of local cases:

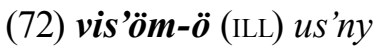

'sicken (word to word to fall into an illness)'

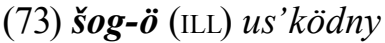

'aggrieve (word to word to let fall into sorrow)'

(74) èbös-ys' (EL) us'ny

'become powerless (word to word to fall from the force)'

Trajectors are alive but conditions themselves are abstract in prototypical situations of the expressions of the condition as it can be seen from the examples. However, lifeless objects can often take different conditions and the condition could be expressed by the objects of material world:

(75) Kyz ögyr-̈̈ (ILL) us'köda da së pečenča pöžala (ÖKK 83) 'I'll make [of you] coals (word to word let fall into coal) and roast hundred pieces of baked vegetables'

(76) köluj pörtny den'ga-ö (ILL) (KRK 522)

'to turn things into money'

(77) ru pörtny va-ö (ILL) (KRK 522)

'condense vapour (word to word transform steam into water)'

The usage of ILL form for expressing entering in some condition could be seen more often. Constructions of that kind 
are formed with the help of verbs pörny, pörtčyny 'to turn, to transform (reflexive)' and pörtny 'to turn, to transform (transitive)' in most cases:

(78) Jeretniča pörtis sijös ruč-ö (KRK 522)

'The witch charmed him into a fox'

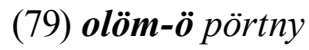

'to realize (word to word to turn into life)'

Additionally, adjectives with verbs puktyny 'to consider (word for word to put, to position)', puks'yny 'to consider (oneself) (word for word to sit down)' (Ludykova 2005: 91-95), us'ködčyny 'to pretend (word for word to rush)', lèččys'ny 'to pretend (word for word to fall, to descend)' are used for marking some condition of form ILL:

(80) ...bur-ö puktö... (Ludykova 2005: 92)

'...honours (word for word (s)he considers [her/him] into good $)$...'

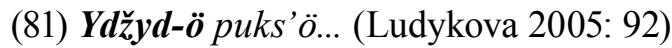

'...had a good opinion of himself (word for word (s)he sits down into big)...'

(82) ...pel'töm-ö us'ködčylis... (Ludykova 2005: 94)

'...pretended as being deaf (word for word rushed into deaf)...'

(83) ...lèččysi jöj-̈̈... (Ludykova 2005: 95)

'...[I] pretended as being fool (word for word descended into fool)...'

A whole layer is formed by the examples of the usage of cases with nouns, which express professions, field of activity etc. that means some function. Staying in some kind of occupation, accession to an office and deposition from post or occupation is expressed in such a case by IN, ILL and EL:

(84) ...kyk vo oli sel'sköj pisar-yn (IN) (ÖKK 82)

'I were (lived as) the village penman (word for word $\underline{i n}$ penman) for two years'

(85) Köt' nin traktorist-̈̈ (ILL) velödčis. Vek nin nadejnöj udž (Popov 2008: 321)

'Anyway, he learned to become a tractor driver (word for word into tractor driver). It's a definite job' 
It's interesting to mention the fact of low dialectical usage of not the terms of occupations or professions, but the metonymical usage of the terms of the objects of activity connected with occupations or the form of activity in such functions:

(86) pors-is' (EL) petis (Guljaev 1961: 28)

'she left the pigsty (word for word came from pig)'

The original ILL form in the meaning of having some kind of occupation at present has got the tendency of blending the forms of instrumental case under the influence of Russian language (Ludykova 2005: 89):

(87) udžalö učitel'-̈̈n

'(s)he's working as a teacher'

The domain of condition in specific cases can have the points of crossing with a scale (see below). As a rule EGR and TERM figure as examples of the usage of cases of that kind:

(88) Tomön, tomön voödčömyd master-ödz (TERM) (ÖKK 91)

'You were young when [you] served Master level (word to word reached to Master)'

(89) Marko vör pörödys'-sjan' (EGR) vois vörpunkt načal'nik-

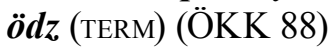

'Marco served (word to word reached) from wood-cutter up to the manager of a forest enterprise'

(90) Sijö 15 vo nin udžalö kusödčys'ön, šoper-sjan’ (EGR) bydmis otrjadsa načal'nik-ödz (TERM) (Komi mu 04.12.2007) 'He has already 15 years worked as a fireman, he has gone his way from a driver up to the manager of the team' The usage of local cases with nouns, which indicate to a process, gives the basis to talk about a transition zone between the domain of condition and event space. The forms of that kind can be more often met in constructions with verbs bos'tčyny, kutčys'ny 'to begin, to start (doing something)', dugdyny 'cut off, quit' and dugödny 'force to quit (doing of something)':

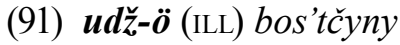

'begin to work (word to word into wrok)'

(92) Rita dugdis grad vesalöm-ys' (EL) ... (ÖKK 84)

'Rita stopped weeding the bed (word to word from weeding the bed)...' 


\section{Scale}

Scale is an abstract cognitive domain, which has got similarities with the physical space in respect of one-dimensionality and in respect of analogous structure with time, which is based on the sequence of location (Vainik 1995: 122-123). Wordslandmarks in the form of TERM and sometimes together in pairs with EGR include the indication on certain locations on cognitive imaginary scale. This can be a scale of the units of measuring and characteristics, quality, steps etc., for example:

(93) ...vitsë sjurs gozj-ödz pö sèki s'ölatö kyjlömaös' Komi muyn byd vo (ÖKK 91)

'...it's said that hazel-hens were got up to 500000 pairs in Komi yearly'

(94) Vo das vit sajyn tani kosk-ödz turun bydmis (Popov 2008: 182)

'About 15 years ago the grass was up to waist here'

(95) ...par”jassö vir-ödz kurččavlis... (Popov 2008: 145)

'...(s)he bit his/her lips till blood came out...'

(96) Sjuran kö tatšöm”jas ulad, lestuk”jas-ödz kosjavlasny (Popov 2008: 18)

'If you meet such kind [of dogs], you'll be torn into pieces'

(97) Tadzi durmyligas mužik”jasly medbur lekarstvo - s'ödödz pinjalöm (Popov 2008: 109)

'The best medicine for such distraction for men is to curse them strongly (word to word till they are black'

The crossings of the domains of the scale and the conditions of the usage of TERM (sometimes in pairs with EGR) with nouns indicating on some profession, the form of activity of a person etc. are frequent. The scale, whereon the concepts expressed by the landmarks are situated, is cognitive imagined in such cases:

(98) Nekodly kovtöm mort-ödz (TERM) drug usi Miš (Popov 2008: 62)

'Misha suddenly fall on the level of an unnecessary man'

(90) Sijö 15 vo nin udžalö kusödčys'ön, šoper-sjan' (EGR) bydmis otrjadsa načal'nik-ödz (TERM) (Komi mu 04.12.2007) 
'He has already 15 years worked as a fireman, he has gone his way from a driver up to the manager of the team'

\section{Domain of abstract relations}

The usage of local cases, which present different abstract relations, can be put in this domain. For example, the material of production in the form of EL is marked as follows:

(99) Stavys tijan pu-ys' (Čuškanzi 31.08.2007)

'You've got everything made from wood'

Similar meaning, which indicates on the composition, acts as a part of the crossing of the domain with social space:

(100) A komandaöj menam dzon'nas tom jöz-ys' (ÖKK 85)

'But all my team [consists] of young people (word to word from young people)'

The forms of ILL can be used for expressing comparison:

(101) Oljaös mam röd-ö kyskö (ÖKK 84)

'Olja is similar to her mother (word to word it tears Olja to her mother)'

But the forms of APPR in constructions with a verb мунны 'to go' give distant similarity:

(102) Ortsysa vid sertiys ëna munis [...] Selifan-lan' (ÖKK 87)

'(S)he strongly resembles [...] Seliphan (word to word goes

to the direction of Seliphan) in looks'

(103) ...vyl' posëlok [...] munis kar-lan'... (ÖKK 87)

'...the new village [...] resembles the town (word to word goes to the direction of the town)'

The local cases can similarly be used for expressing certain relations to a landmark:

(104) povny köin-ys' (EL)

'to afraid of wolf (word to word from a wolf)'

(105) Jandzim völi mam-sjan'-ys i jöz-sjan'-ys (EGR) ... (ÖKK 88)

'It was a shame before his/her mother and people (word to

word from his/her mother and people)'

(106) ...gažöj tè-ys’ (EL) byröma (Popov 2008: 49)

' [I] missed you (word to word the joy from you has ended)' 
(107) èskyny pobeda-ö (ILL) (ÖKK 83)

'to believe in victory (word to word into victory)'

EL can express the importance of compensation (Guljaev 1961: 12):

(108) ...ydžyd don-ys' (Popov 2008: 99)

'for a high price (word to word from price)'

... and mark the reason:

(109)...ť̌syg”jalöm-ys' [...] omöl’tčöma (ÖKK 86)

'he thinned from starvation'

EGR may figure in the last meaning in some dialects:

(110) vina jü̈m-sjan' (ÖKK 88)

'from drinking wine'

The abstract relations designated by local cases, are not settled by this list of values. They can mark the instrument, way of acting, and they can have many other functions. Nouns, which act as landmarks in these or many other examples, recognize the crossing of the domains of abstract connections with some other domains, which were observed above.

\section{Conclusions}

Consequently, the observation of some amount of concrete examples demonstrated the most frequent cognitive domains reflecting the local cases of Komi language in semantics. This choice of cognitive domains depicts a matrix wherein the central place has got mentally projected three-dimensional physical space. All the other domains are connected with physical space having zones of direct crossing with it or, for example, revising certain structural models, which function in them. Some transitional parts can exist between different domains. The observed cognitive domains can be imagined in the form of the fmatrix (Fig. 2). 


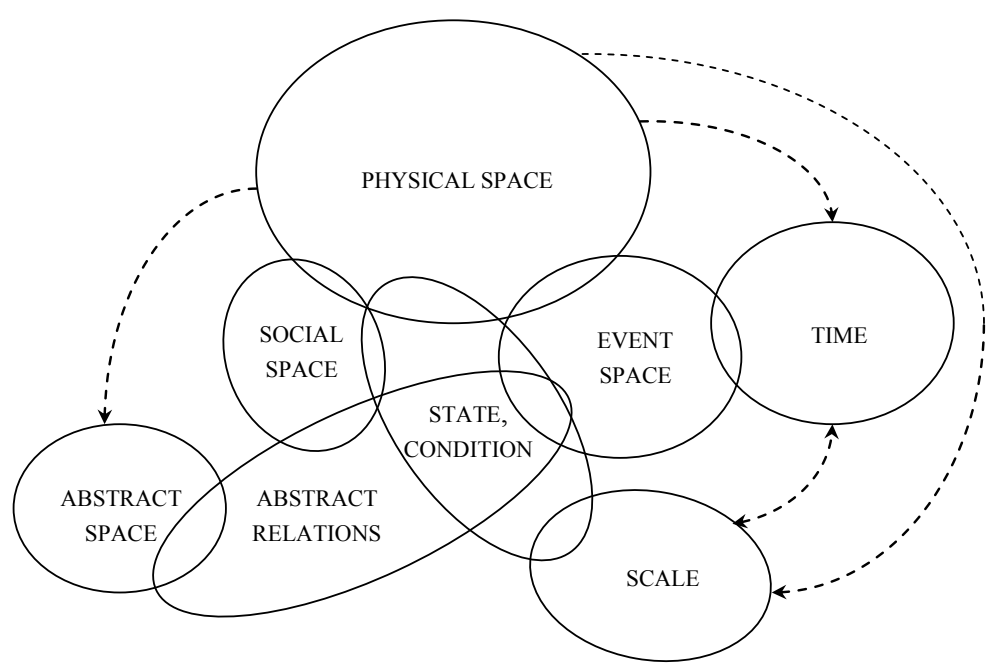

Figure 2. Matrix of cognitive domains for spatial cases of Komi language.

\section{Acknowledgements}

The author thanks Meelis Raju for translating the article into English, and two anonymous reviewers for their valuable comments and feedback.

\section{Address:}

Nikolay Kuznetsov

Institute of Estonian and General Linguistics

University of Tartu

Jakobi 2

51004 Tartu, Estonia

E-mail: nikolai@ut.ee 


\section{Sources of examples}

$\check{C}$ uškanzi, the monthly magazine. Syktyvkar.

Guljaev, Evgenij Semënovič (1961) s'-ovye padežnye suffiksy v komi jazyke (v sravnitelno-istoričeskom osveščenii). Syktyvkar.

Komi mu, newspaper. Syktyvkar.

KRK = Beznosikova, Ljucija Mixajlovna, Evgenija Avenirovna Ajbabina, Raisa Ivanovna Kosnyreva (2000) Komi-roč kyvčukör. Syktyvkar: Komi nebög ledzanin.

Ludykova, Valentina Mixajlovna (2005) Predikativnoe prilagatel'noe v komi jazyke. Syktyvkar: Izdatel'stvo SyktGU.

Nekrasova, Galina Aleksandrovna (1998) "Padež". In Galina Vladimirovna Fedjunëva, ed. Komi jazyk. Enciklopedija, 336-337. Moskva: Izdatel'stvo DiK.

Parma gor, newspaper. Ust'-Kulom.

Popov, Aleksej (2008) Grezd: Poves'tjas da vis'tjas. Syktyvkar: OOO “Anbur”. Timin, Vladimir (2000) Ežva Perymsa zonka. Syktyvkar: Esköm Izdatel'stvo. Vyl' tujöd, newspaper. Udora.

ÖKK = Fedjunëva, Galina Vladimirovna, ed. (2000) Önija komi kyv. Morfologija. Syktyvkar.

\section{References}

Anderson, John Mathieson (1971) The grammar of case: towards a localistic theory. Cambridge: Cambridge University Press.

Guljaev, Evgenij Semënovič (1961) s'-ovye padežnye suffiksy v komi jazyke (v sravnitelno-istoričeskom osveščenii). Syktyvkar.

Frawley, William (1992) Linguistic semantics. Hillsdale, New Jersey, Hove and London: Lawrence Erlbaum Associates, Publishers.

Kondrat'eva, Natal'ja Vladimirovna (2011) Kategorija padeža imeni suščestvitel'nogo $v$ udmurtskom jazyke. Iževsk: Izdatel'stvo "Udmurtskii universitet".

Ludykova, Valentina Mixajlovna (2005) Predikativnoe prilagatel'noe v komi jazyke. Syktyvkar: Izdatel'stvo SyktGU.

Nekrasova, Galina Aleksandrovna (1998) "Padež". In Galina Vladimirovna Fedjunëva, ed. Komi jazyk. Enciklopedija, 336-337. Moskva: Izdatel'stvo DiK.

SKJa = Lytkin, Vasilij Il'ič, ed. (1955) Sovremennyj komi jazyk. Čast' pervaja. Fonetika, leksika, morfologija. Syktyvkar: Komi knižnoje izdatel'stvo.

Vainik, Ene (1995) Eesti keele väliskohakäänete semantika kognitiivse grammatika vaatenurgast. Tallinn.

ÖKK = Fedjunëva, Galina Vladimirovna, ed. (2000) Önija komi kyv. Morfologija. Syktyvkar. 
Kokkuvõte. Nikolay Kuznetsov: Komi keele kohakäänete kognitiivse domeeni maatriks. Kognitiivse lingvistika teooria järgi on kohakäänete semantika sisemiselt organiseeritud tunnetusvaldkondade kompleksse maatriksina. Iga valdkond kujutab endast konkreetsete situatsioonide üldistust. Valdkondade ristumiskohad viitavad üleminekualale ühest valdkonnast teise. Sinna kuuluvad käändekasutused on tsentraalsemate ehk prototüüpsemate suhtes perifeersed. Kognitiivsete valdkondade maatriksis on keskne koht ruumil, mis pole enam millekski taandatav ja mis on põhivaldkonnaks kõikidele kohakäänetele. Ülejäänud valdkonnad on seotud ruumi valdkonnaga, omades sellega enam või vähem ühisjooni. Artiklis on analoogselt eesti keele väliskohakäänete kognitiivsete valdkondade analüüsiga (vt Vainik 1995) esitatud kognitiivsete valdkondade maatriks komi keele kohakäänetele.

Märksõnad: kognitiivne lingvistika, kognitiivne valdkond, valdkondade maatriks, käänete semantika, kohakäänded, komi keel 